\title{
STUDI KASUS LINGUISTIK FORENSIK: HOAKS REKAMAN SUARA YANG DIDUGA GATOT NURMANTYO
}

\author{
Ghozali Saputro \\ Universitas Negeri Yogyakarta \\ email: saputra.13april@gmail.com
}

\begin{abstract}
(Title: A Forensic Linguistic Study Case: Hoax of Recorded Voice Who Was Allegedly From Gatot Nurmantyo). This study aimed to describe the comparison between languages on Gatot Nurmantyo's Similar Voice Sample (SVS) recording with language on Gatot Nurmantyo's Original Voice Sample (OVS) recordings. The data source were one SVS record and three OVS records (OVS01-OVS03). Data were collected through observation, copying, and recording. The instrument for data collection was in the form of human, researcher himself with the recording devices and stationery. The analysis was carried out comprehensively with a review of various aspects including Phonology, Sociolinguistics, Discourse, and Stylistics. The results of the study were as follows. First, there were significant differences between languages on SVS and language on all three OVS recordings in terms of Sociolinguistic, Discourse and Stylistic aspects. Second, on the Phonological aspect there was a tendency for the similarities between language on the SVS recording and language on all three OVS recordings in several parts including the duration of word utterance, the energy intensity of the word utterance, and the sound of the words. Therefore, it could be concluded that on a Classical Likelihood Scales, the SVS and OVS recordings were not from the same speaker.
\end{abstract}

Keywords: forensic linguistic, comprehensive, recording, Praat

\section{PENDAHULUAN}

Istilah Linguistik Forensik mulai populer sejak seorang linguis bernama Jan Startvik mengungkap sebuah kasus pembunuhan dalam laporannya berjudul The Evans Statements: A Case for Forensic Linguistics pada tahun 1968. Dalam laporan tersebut, ia menjelaskan bahwa empat pernyataan yang telah dibuat oleh polisi tentang Timothy Evans yang membunuh istri dan bayi perempuannya memiliki gaya tata bahasa yang berbeda. Sejak saat itu istilah Linguistik Forensik banyak digunakan seiring dengan banyaknya kajian yang dilakukan. Yang menarik adalah Coulthard dan Johnson (2007: 18) menyebut bahwa hampir 20 tahun sebelumnya, istilah Forensic English telah digunakan oleh Philbrick (1949) dalam bukunya yang berjudul English, Language and the Law: the Semantics of Forensic English, tetapi istilah tersebut tidak pernah digunakan.

Susanto (2017: 5) mengungkapkan bahwa di kancah internasional, hasil-hasil kajian Linguistik Forensik telah berguna untuk membantu investigasi pada berbagai kasus. Di antaranya kasus-kasus pembunuhan, penculikan, korupsi, plagiarisme, terorisme, cyber crime dan juga untuk keperluan intelijen ( $\mathrm{na}$ tional and international security). Sekarang pertanyaanya adalah bagaimana dengan Indonesia? Sejauh mana perkembangan Linguistik Forensik di Indonesia?

Lebih lanjut, Susanto (2017: 5-6) menjelaskan bahwa Indonesia tentunya dapat menjadi "surga" bagi para peneliti di bidang Linguistik Forensik. Hal ini dimungkinkan karena Indonesia adalah negara kepulauan sehingga wajar bila Indonesia mempunyai beragam bahasa. Semakin banyak bahasa dan penutur yang multilingual di Indonesia semakin besar pula potensinya untuk diteliti. Namun, hal ini juga akan menjadi tantangan tersendiri bagi para peneliti. Sebagai contoh, Forensic Speaker Identification (FSI). Di Indonesia FSI sudah dikenal sejak 2008. Sejak saat itu, analisis bukti rekaman sudah dimanfaatkan untuk menyelesaikan kasus-kasus korupsi dan pembunuhan. Namun, dalam berbagai penelitian yang telah dilakukan, FSI di Indonesia masih 
belum maksimal. Salah satunya dikarenakan unsur-unsur yang dipakai dalam FSI masih belum bisa menutup celah terhadap suara-suara yang disamarkan. Selain itu juga belum dapat digunakan untuk mengantisipasi kondisi multilingual di Indonesia. Tantangan-tantangan seperti ini dapat menjadikan kajian-kajian Linguistik Forensik terus berkembang.

Dalam 15 tahun terakhir, frekuensi kajian Linguistik Forensik tumbuh dengan cepat. Terbukti bahwa pengadilan di berbagai negara telah meminta bahasawan untuk menjadi saksi ahlidalam misi membantu menyelesaikan berbagai jenis kasus. Seperti di Inggris pada tahun 2008, Dr. Tim Grant, seorang ahli Linguistik Forensik dari Universitas Aston berhasil menemukan pembunuh atas kasus kematian perempuan bernama Jenny Nicholl. Melalui pesan yang dikirim dari ponsel Jenny Nicholl sebelum ia dinyatakan hilang, Dr.Tim Grant berhasil membuktikan bahwa pesan tersebut mempunyai kemiripan gaya dengan pesan yang ditulis oleh seseorang bernama David Hodgson.

Selain itu, di Indonesia juga beberapa kali telah terjadi kasus yang melibatkan bahasawan menjadi saksi ahli. Contohnya pada kasus penghinaan kota Yogyakarta oleh Florence Sihombing pada 2015 lalu, Drs. Ibnu Santoso, M.Hum., dosen Fakultas Bahasa dan Seni Universitas Negeri Yogyakarta hadir di persidangan lanjutan selaku saksi ahli bahasa terkait kasus tersebut. Ibnu Santoso mengungkapkan bahwa kata tolol dan takberbudaya termasuk menghina dan merendahkan. Secara Linguistik Forensik ada makna provokasi dalam kalimat itu. Provokasi merupakan ajakan untuk sesuatu yang tidak baik.

Baru-baru ini, beredar kasus terkait pemilu 2019 yang mencatut mantan Panglima TNI, Jenderal Purnawirawan Gatot Nurmantyo (GN). Kasus tersebut berupa beredarnya rekaman suara yang diduga mirip GN yang berbicara tentang kecurangan pemilu 2019. Pria tersebut mengatakan bahwa kecurangankecurangan itu merugikan salah satu pasangan calon. Pria tersebut juga berbicara tentang masalah keamanan NKRI dan meminta publik mempercayakannya kepada TNI dan Polri. Hal ini membuat GN lantas memberikan penjelasan dalam akun instagram pribadinya bahwa suara yang terdengar dalam rekaman tersebut bukan suara dirinya. Oleh karena itu, pada penelitian ini, Linguistik Forensik secara komprehensif akan digunakan untuk membandingkan bahasa yang digunakan antara rekaman yang beredar tersebut dengan bahasa yang digunakan oleh GN dalam berbagai acara.

Linguistik Forensik merupakan cabang ilmu linguistik terapan. Hal itu senada dengan pendapat Susanto (2017: 5) yang menyebut bahwa Linguistik Forensik termasuk dalam kajian ilmu linguistik terapan. Begitu juga dengan pendapat yang diungkapkan oleh Olsson (2004) bahwa forensic linguistics is the application of linguistics to legal issues atau yang berarti Linguistik Forensik adalah aplikasi ilmu linguistik pada bidang hukum. Artinya, dalam penerapan, Linguistik Forensik banyak berhubungan dengan alat-alat bukti kebahasaan untuk kepentingan hukum. Misalnya, kajian bahasa perundang-undangan, bahasa persidangan, interogasi oleh pihak kepolisian terhadap orang yang diduga melakukan kejahatan dan bahkan penganalisaan terhadap rekaman suara percakapan demi kepentingan investigasi.

Fonologi berperan penting dalam upaya menganalisis terhadap suara rekaman yang menjadi alat bukti kebahasaan untuk kepentingan hukum tersebut. Salah satu cabang ilmunya yang berkaitan Linguistik Forensik, yaitu Fonetik Forensik digunakan dalam analisis pada penelitian ini. Mukattash (2016: 32) mengatakan sejak awal kemunculannya sebagai sebuah studi yang berbeda pada 1990-an, Fonetik Forensik telah menangani kasus-kasus pengadilan seperti identifikasi (suara) penutur, otentikasi rekaman dan perselisihan dalam pembicaraan. Lebih lanjut, ia mengatakan analisis fonetik bertujuan untuk memeriksa dan mengevaluasi fitur fonetik dalam dua atau lebih sampel suara, seperti: perbedaan gaya antarsampel, cara fitur variabel dikuantifikasi, d1l. Analisis tersebut dilakukan dengan cara mengetahui atau menyelidiki ciri fisik dari bunyi bahasa. Dengan kata lain, fitur-fitur Fonetik Akustiklah yang akan banyak bekerja untuk menganalisis. 
Lindh (2017: 11) mengungkapkan bahwa penganalisisan rekaman terdiri atas tiga tahap independen. Pertama, seorang analis mendengarkan rekaman dan memilih bagian yang akan digunakan untuk tahap kedua dan ketiga sambil menyalin dan menganalisis perilaku bahasa tersangka dan rekaman yang dipertanyakan. Kedua, bagian ini terdiri atas pengukuran fitur akustik vokal yang berbeda seperti fundamental frekuensi, kecepatan berbicara, dan forman vokal. Ketiga, Bagian ini disebut sebagai perbadingan kualitas suara biometrik menggunakan sistem otomatis. Sistem ini melibatkan model suara-suara umum. Dalam hal ini, fitur akustik berupa ekstraksi dari rekaman suara tersangka dan rekaman suara yang dipertanyakan. Fitur akustik yang sama kemudian diuji dan dilihat dari perolehan skor kemiripan suaranya. Dengan cara tersebut kemudian analis dapat memberikan rasio antara dua hipotesis: (1) suara uji sama dengan suara tersangka atau (2) suara uji berbeda dengan suara tersangka.

French (2017) mengungkapkan bahwa sampai akhir tahun 1980-an, ahli fonetik yang terlibat dalam Forensic Speech Comparation pada umumnya mengungkapkan kesimpulan mereka tentang penutur yang diketahui/tidak diketahui (identity/non-identity speaker) dalam kerangka kerja biner 'ya'/'tidak'. Setelah dekade itu, praktik ini sebagian besar telah ditinggalkan karena adanya Skala Kemungkinan Klasik (Classical Likelihood Scales). Skala tersebut mengandung ekspresi verbal bukan numerik dari kemungkinan (likelihood) dalam melihat fakta bahwa tidak ada statistik populasi yang tersedia untuk sebagian besar fitur yang dianalisis oleh ahli Fonetik Forensik dalam perjalanan perbandingan mereka. Jadi, misalnya, salah satu dari tersangka atau penutur kriminal tersebut mungkin mempunyai kekhususan, yakni kekhususan dalam pengucapan /s/ atau pengaturan vokal taring laring, tetapi tidak ada satu basis data yang dapat menentukan kejadian ini dilakukan oleh baik secara individu atau berkelompok.

Terlepas dari bunyi-bunyi bahasa, tentu secara sosiolinguistik penggunaan bahasa pada rekaman tersebut perlu dicermati guna mendeteksi adanya kontak bahasa yang berbeda atau sama di antara keduanya. Chaer dan Agustina (2010) menyebutkan hal-hal yang diakibatkan oleh adanya kontak bahasa meliputi bilingualisme, diglosia, alih kode, campur kode, interferensi, integrasi, konvergensi dan pergeseran bahasa. Dari begitu banyaknya hal yang diakibatkan oleh kontak bahasa, tidak semuanya akan dibahas dalam penelitian ini karena data yang diperoleh menunjukkan kecenderungan gejala interferensilebih banyak.

Hartmann dan Stork (dalam Pitoyo: 2017) mendefinisikan interferensi sebagai suatu kekeliruan yang disebabkan terbawanyan kebiasaan-kebiasaan ujaran bahasa ibu atau bahasa pertama ke dalam bahasa kedua. Interferensi terjadi sebagai akibat dari penguasaan bahasa pertama lebih dominan dibandingkan bahasa keduanya. Dalam hal ini, B1-nya adalah bahasa daerah dan B2-nya adalah bahasa Indonesia. Penggunaan bahasa daerah yang sudah terlebih dahulu dikuasai akan berpengaruh saat seseorang menggunakan bahasa Indonesia sebagai bahasa kedua. Hidayat dan Setiawan (2015: 157) menjelaskan bahwa interferensi dapat terjadi pada tiga tataran, yakni tataran Fonologi, gramatikal dan leksikal (kata).

Selain itu, bahasa rekaman tersebut tentu harus dilihat secara keseluruhan, yakni dari sudut pandang Wacana. Menurut Tarigan (2009: 19), Wacana adalah satuan bahasa terlengkap dan tertinggi atau terbesar di atas kalimat atau klausa dengan koherensi dan kohesi tinggi yang berkesinambungan yang mempunyai awal dan akhir nyata disampaikan secara lisan atau tertulis. Hubungan kohesif di dalam Wacana ditandai dengan pemarkah gramatikal (kohesi gramatikal) dan pemarkah leksikal (kohesi leksikal). Halliday dan Hasan (1976: 5-6) menjelaskan bahwa pemarkah gramatikal ini terdiri atas empat jenis, yakni pengacuan (referensi), penyulihan (substansi), pelesapan (elipsis) dan perangkaian (konjungsi). Sementara itu, pemarkah leksikal mencakup pengulangan (repetisi), padan kata (sinonimi), lawan kata (antonimi), sanding kata (kolokasi), serta hubungan atas-bawah (hiponimi).

Dalam menyampaikan gagasannya, setiap penutur berbeda-beda. Hal tersebut disebabkan salah satunya karena perbendaharaan kata masing-masing. Perbendaharaan kata 
yang dimiliki oleh seseorang erat kaitannya dengan pemilihan kata atau diksi. Dalam Stilistika, pemilihan kata mencerminkan perasaan atau sikap seseorang ketika ia berkomunikasi. Hal tersebut sesuai dengan pendapat yang dikemukakan oleh Widyamartaya (1990: 45) bahwa pilihan kata atau diksi adalah kemampuan seseorang membedakan secara tepat nuansa-nuansa makna sesuai dengan gagasan yang ingin disampaikannya dan kemampuan tersebut hendaknya disesuaikan dengan situasi dan nilai rasa yang dimiliki oleh sekelompok masyarakat dan pendengar atau pembaca.

\section{METODE}

Penelitian ini merupakan penelitian deskriptif kualitatif. Subjek penelitian ini adalah suara rekaman yang diduga mirip mantan Panglima TNI, Jenderal Purnawirawan GN dan tiga sampel suara asli GN sebagai pembanding. Suara rekaman mirip GN tersebut berdurasi 2 menit 45 detik diunggah oleh akun facebook Comedy Room pada Jumat, 26 April 2019. Sementara itu, tiga sampel suara asli GN antara lain (1) diambil dari rekaman pidato GN ketika menghadiri acara Pidato Kebangsaan Prabowo Subianto (12/04/19), (2) diambil dari rekaman program Mata Najwa edisi "Menjaga Bhinneka" (2/11/16)dan (3) diambil dari rekaman program Indonesia Lawyers Club edisi "Setelah 411" (8/11/16).Ketiga sampel tersebut kemudian disebut dengan kode SSA01, SSA02, SSA03 secara berurutan.

Objek penelitian ini adalah bunyibunyi ujar yang diucapkan di dalam rekaman tersebut. Pengumpulan data dilakukan dengan observasi, penyalinan dan pencatatan. Instrumen pengumpul data berupa manusia, yaitu peneliti sendiri dilengkapi dengan alat rekam dan alat tulis.Kajian Linguistik Forensik sebaiknya memang dilakukan secara komprehensif. Hal itu senada dengan pendapat yang diungkapkan oleh Subyantoro (2017) dalam situs berita yang diunggah oleh Universitas Negeri Semarang pada $4 / 8 / 17$, yakni menurutnya pengembangan Linguistik Forensik harus dilakukan secara komprehensif dengan memanfaatkan aneka subdisiplin yang sudah ada. Oleh karena itu, penelitian ini ditinjau dari sudut pandang
Fonologi, Sosiolinguistik, Wacana, dan Stilistika.

Pada aspek Fonologi, analisis dilakukan dengan memasukkan data berupa rekaman ke dalam sebuah perangkat lunak bernama Praat. Perangkat tersebut digunakan oleh para ahli bahasa untuk menganalisis suara/tuturan. Perangkat lunak ini dapat diunduh dari situs http://www.fon.hum.uva.nl/praat/. Pada halaman ini juga terdapat tutorial manual Praat untuk pemula yang ditulis oleh Sidney Wood. Praat adalah alat yang sangat fleksibel untuk melakukan analisis lisan. Perangkat lunak ini menawarkan berbagai prosedur termasuk analisis spektrografi, sintesis artikulasi, dan jaringan saraf. Selain di bidang linguistik, Praat juga dapat digunakan di bidang kedokteran, yakni pada gangguan komunikasi sebagai bagian dari evaluasi akustik baik sampel suara maupun suara asli.

Dari perangkat tersebut dapat diketahui informasi terkait bunyi bahasa secara fisik pada setiap fitur untuk membandingkan Sampel Suara Mirip (SSM) dan Sampel Suara Asli (SSA).Selain itu, pengucapan bunyi kata tertentu juga dicermati guna mengetahui perbedaan atau persamaan pengucapan pada setiap rekaman. Pada aspek Sosiolinguistik, analisis dilakukan dengan mengidentifikasi bahasa yang digunakan dan interferensi bahasayang terlibat. Pada aspek Wacana, analisis dilakukan dengan mengidentifikasi kohesi yang digunakan. Pada aspek Stilistika, analisis dilakukan dengan mengidentifikasi nuansa pemilihan katayang digunakan.Pada akhirnya, penelitian ini akan dapat ditarik kesimpulannya dengan Skala Kemungkinan Klasik (Classical Likelihood Scales) untuk mengetahui bahwa penutur pada rekaman SSM dan SSA berasal dari orang yang sama atau berbeda.

\section{HASIL DAN PEMBAHASAN}

Berdasarkan analisis yang dilakukan secara komprehensif, perbandingan bahasa pada rekaman SSM dan SSA dapat dinyatakan dalam Skala Kemungkinan Klasik (ClassicalLikelihoodScales), yakni terdapat pada skala 4: kemungkinan besar bahwa rekaman SSM dan SSA bukan dari penutur yang sama. Hal terse- 
but didasarkan pada hasil analisis Fonologi, Sosiolinguistik, Wacana dan Stilistika bahwa terdapat perbedaan yang signifikan pada aspek Sosiolinguistik, Wacana dan Stilistika. Namun, hanya pada aspek Fonologilah kecenderungan kemiripan antara bahasa rekaman SSM dan SSA tersebut muncul. French (2017) menyatakan bahwa skala kemungkinan klasik cukup bervariasi dalam hal detailnya dan cukup khas dari yang digunakan pada umumnya, yakni sebagai berikut.

5 Kemungkinan sangat besar bahwa $\mathrm{X}$ dan $\mathrm{Y}$ adalah penutur yang sama

4 Kemungkinan besar bahwa X dan Y adalah penutur yang sama

3 Kemungkinan bahwa $\mathrm{X}$ dan $\mathrm{Y}$ adalah penutur yang sama

2 Kemungkinan kecil bahwa $\mathrm{X}$ dan $\mathrm{Y}$ adalah penutur yang sama

1 Kemungkinan sangat kecil bahwa $\mathrm{X}$ dan $\mathrm{Y}$ adalah penutur yang sama

0 Tidak ada kemungkinan

1 Kemungkinan sangat kecil bahwa $\mathrm{X}$ dan $\mathrm{Y}$ bukan penutur yang sama

2 Kemungkinan kecil bahwa $\mathrm{X}$ dan $\mathrm{Y}$ bukan penutur yang sama

3 Kemungkinan bahwa $\mathrm{X}$ dan $\mathrm{Y}$ bukan penutur yang sama

4 Kemungkinan besar bahwa $\mathrm{X}$ dan $\mathrm{Y}$ bukan penutur yang sama

5 Kemungkinan sangat besar bahwa X dan $\mathrm{Y}$ bukan penutur yang sama

\section{Aspek Fonologi}

Pada aspek Fonologi, ditinjau dari subbidang Fonetik Akustik, yakni dengan memeriksa informasi fisik bunyi seperti(1) durasi, (2) frekuensi, (3) intensitas energi, (4) forman pada pengucapan kata tertentu. Kemudian, dicermati pula bunyi pengucapannya guna mengetahui perbedaan dan persamaan yang ada pada setiap rekaman.Pada aspek ini, dipilih satu kata tertentu yang diucapkan dalam semua rekaman, yakni kata Indonesia berbunyi [indonèsia]. Hal tersebut dimaksudkan agar hasil analisis yang diperoleh akurat dan seimbang antara rekaman SSM ataupun SSA.

Sebelum dilakukan penganalisisan SSM dengan perangkat lunak Praat, setiap rekaman didengarkan dan disalin satu persatu. Selama proses penyalinan, peneliti mencermati kata-kata tertentu yang sama-sama diucapkan dalam setiap rekaman untuk dianalisis. Pemilihan kata yang sama dimaksudkan untuk menghindari ketimpangan dalam analisis dan untuk menyamakan objek bandingan pada masing-masing rekaman. Berikut adalah tabel hasil analisis Fonetik Akustik pengucapan kata Indonesia melalui perangkat lunak bernama Praat.

Pada rekaman SSM, bunyi [indonèsia] diucapkan selama 0.562976 detik (1.776/s). Durasi tersebut cenderung mempunyai kemiripan dengan rekaman SSA02, yakni 0.539233 $(1.854 / \mathrm{s})$. Rekaman SSM pada pengucapan kata Indonesia mempunyai fundamental frekuensi 107.9 Hz. Fundamental frekuensi adalah frekuensi terendah yang dihasilkan oleh gerakan (osilasi) seluruh objek. Rata-rata intensitas energiyang dihasilkan adalah $78.97009834060798 \mathrm{~dB}$ dan cenderung mirip dengan intensitas energi pada remakan SSA03, yakni 79.02895534199254 dB.Sementara itu, rata-rata forman pada rekaman SSM tersebut adalah $565.7690121033186 \mathrm{~Hz}$. Forman adalah titik-titik yang membentuk garis horizontal pada spektogram. Selain dua fitur pada masing-masing dua rekaman tersebut, hasil analisis fitur Fonetik Akustik rekaman SSM dan ketiga rekaman SSA menunjukkan perbedaan yang signifikan. Berikut ini merupakan gelombang bunyi dan spektogram yang dihasilkan

Tabel 1. Informasi Fonetik Akustik Pengucapan Kata Indonesia melalui Perangkat Lunak Praat

\begin{tabular}{clcccc}
\hline No. & Rekaman & Durasi & $\begin{array}{c}\text { Fundamental } \\
\text { Frekuensi }\end{array}$ & Intensitas Energi & Forman \\
\hline 1. & SSM & $0.562976(1.776 / \mathrm{s})$ & $107.9 \mathrm{~Hz}$ & $78.97009834060798 \mathrm{~dB}$ & $565.7690121033186 \mathrm{~Hz}$ \\
2. & SSA01 & $0.698960(1.431 / \mathrm{s})$ & $181 \mathrm{~Hz}$ & $60.62129123225925 \mathrm{~dB}$ & $678.4116420235866 \mathrm{~Hz}$ \\
3. & SSA02 & $0.539233(1.854 / \mathrm{s})$ & $131.7 \mathrm{~Hz}$ & $67.56745731295209 \mathrm{~dB}$ & $461.08202378569354 \mathrm{~Hz}$ \\
4. & SSA03 & $0.359621(2.781 / \mathrm{s})$ & $146.2 \mathrm{~Hz}$ & $79.02895534199254 \mathrm{~dB}$ & $676.9970587327038 \mathrm{~Hz}$ \\
\hline
\end{tabular}




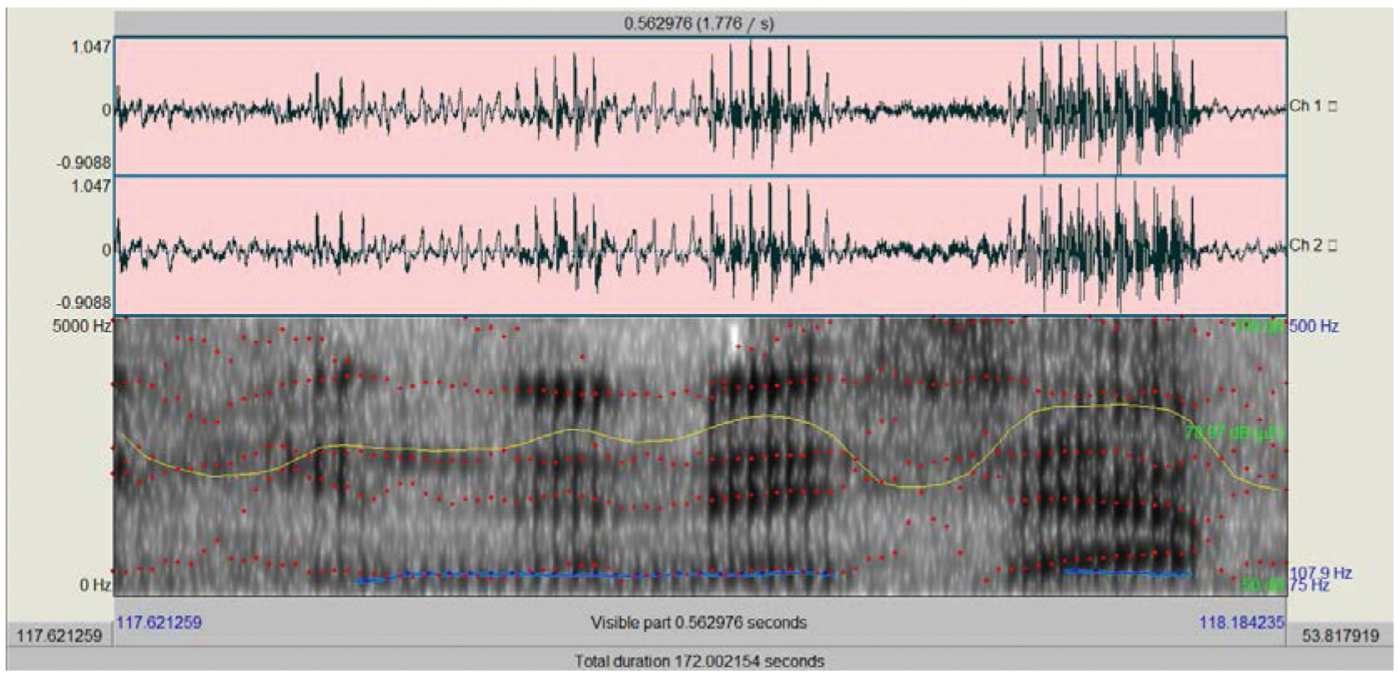

Gambar 1. Bentuk Gelombang dan Spektogram SSM bunyi [indonèsia]

oleh SSM. Bagian yang berwarna merah muda adalah gelombang bunyi [indonèsia] dan di bawahnya adalah spektogram yang dilengkapi dengan garis fundamental frekuensi (biru), forman (merah), dan intensitas (kuning).

Dengan informasi pada fitur-fitur tersebut, tentu belum cukup untuk dapat dikatakan bahwa SSM dan SSA merupakan suara-suara yang bersumber dari penutur yang sama atau berbeda. Oleh karena itu, pada bagian ini peneliti menampilkan grafik analisis periodisasi untuk mengetahui area frekuensi selama bunyi [indonèsia] diucapkan dalam masing-masing rekaman. Pada rekaman SSA01, SSA02 dan SSA03, area frekuensi pengucapan bunyi [indonèsia] di antara $100 \mathrm{~Hz}$ hingga $200 \mathrm{~Hz}$. Frekuensi tersebut juga terlihat fluktuatif. Namun, pada rekaman SSM, area frekuensi pengucapan bunyi [indonèsia] terlihat sangat rendah, yaitu hanya berkisar di area $100 \mathrm{~Hz}$. Grafik frekuensinya juga tidak terlihat fluktuatif.

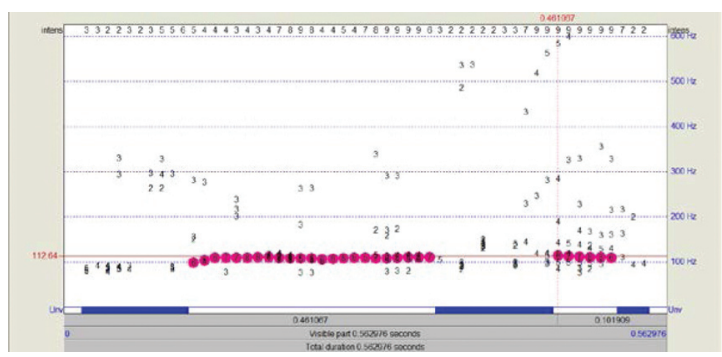

Gambar 2. Diagram Frekuensi SSM

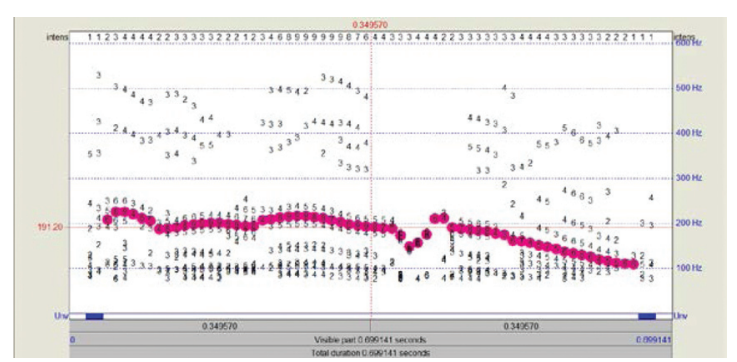

Gambar 3. Diagram Frekuensi SSA01

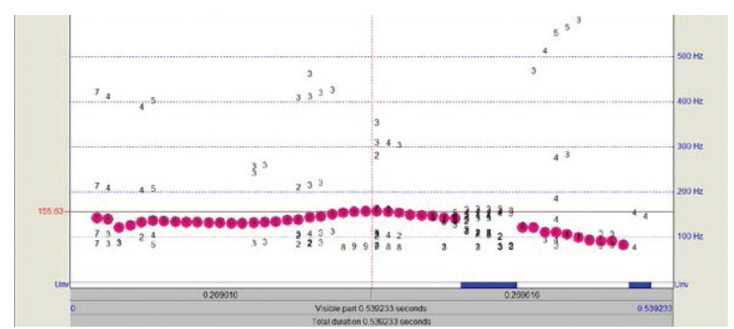

Gambar 4. Diagram Frekuensi SSA02

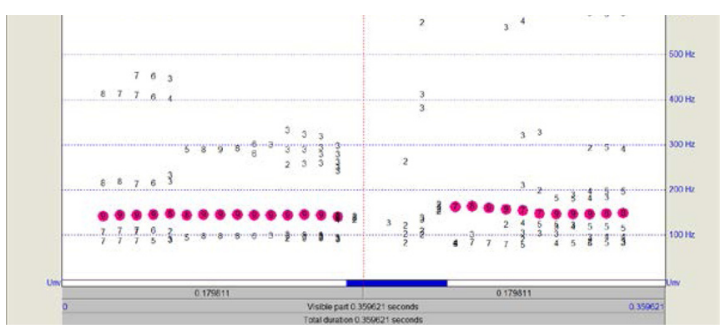

Gambar 5. Diagram Frekuensi SSA03

Selanjutnya, yang perlu dicermati adalah tingkat intensitas energi pada masing-masing rekaman. Tidak dapat dipungkiri bahwa setiap rekaman menghasilkan jumlah energi 
yang berbeda-beda. Berikut adalah grafik intensitas energi setiap rekaman.

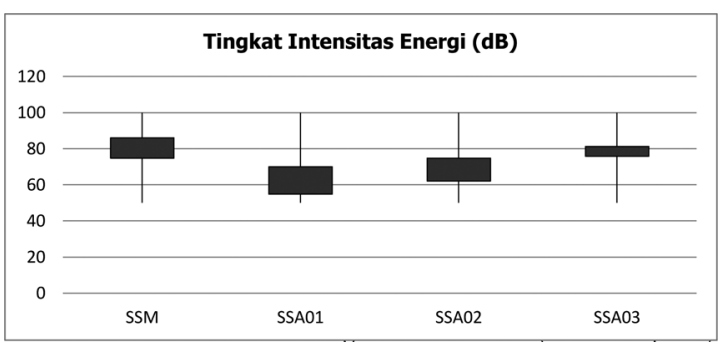

Gambar 6. Diagram Intensitas Energi SSM dan SSA

Tingkat intensitas energi pada rekaman SSM menunjukkan perolehan angka pada kisaran $74.73 \mathrm{~dB}$ hingga $86.06 \mathrm{~dB}$. Perolehan angka tersebut menunjukkan tingkat intensitas energi yang hampir sama dengan rekaman SSA03, yakni $75.74 \mathrm{~dB}$ hingga $81.25 \mathrm{~dB}$. Sementara itu, tingkat intensitas energi pada rekaman SSA01, yakni 54.88 dB hingga 69.91 $\mathrm{dB}$ menunjukkan perolehan angka yang hampir sama dengan rekaman SSA02, yaitu 62.14 dB hingga 74.74 dB. Sekali lagi, fitur analisis menggunakan Praat ini hanya untuk mengetahui informasi fisik terkait bunyi bahasa yang dianalisis sehingga belum dapat dipastikan bahwa penutur berasal dari orang yang sama atau berbeda.

Oleh karena itu, penelitian dilanjutkan dengan analisis pada bagian lain. Rekaman didengarkan oleh penelitisecara berulang-ulang untuk mencermati dan mendengarkan dengan seksama pada bunyi [indonèsia]. Menurut Kamus Besar Bahasa Indonesia (luring), bunyi tersebut seharusnya diucapkan [indonèsia]. Namun, peneliti menemukan fakta bahwa hanya pada rekaman SSM-lah bunyi tersebut diucapakan sebagaimana mestinya. Sementara itu, pada rekaman SSA01, SSA02 dan SSA03 kata Indonesia diucapkan menjadi [éndonèsia] bukan [indonèsia]. Fonem /é/ diucapkan seperti ketika seseorang mengucapkan kata lele/lélé/. Berikut adalah tabel 2 hasil analisis bunyi kata tertentu pada setiap rekaman.

Selain bunyi [i] berubah menjadi [é], pengucapan bunyi [aw/au] juga berubah menjadi [o] ditemukan pada semua rekaman, tetapi dengan kosakata yang berbeda. Pada rekaman SSA01 dan SSA02, kosakata tersebut adalah saudara, yang diucapkan menjadi [sodara]. Pada rekaman SSA01 dan SSA03, kosakata tersebut adalah beliau, yang diucapkan menjadi [bəlio]. Pada rekaman SSM dan SSA01, kosakata tersebut adalah kalau, yang diucapkan menjadi [kalo]. Rekaman SSM juga mempunyai kesamaan dengan rekaman SSA02, yakni penambahan bunyi [A] pada akhir kata juga sehingga kata tersebut diucapkan menjadi [jugaA].

\section{Aspek Sosiolinguistik}

Fenomena perubahan pengucapan bunyi kata tersebut dapat dicurigai sebagai sebuah dampak dari adanya interferensi bahasa pada subbidang Sosiolinguistik. Secara keseluruhan bahasa yang digunakan dalam setiap rekaman adalah bahasa Indonesia, tetapi perbedaanya adalah bahasa dalam rekaman tersebut terinterferensi oleh bahasa daerah yang berbeda. Berikut adalah tabel 3 analisis penggunaan bahasa pada setiap rekaman.

GN adalah orang Jawa asli. Ia lahir di Tegal, Jawa Tengah pada 13 Maret 1960. Oleh karena itu, hal pengucapan [indonèsia] menjadi [éndonèsia] merupakan suatu bentuk kewajaran. Gejala tersebut oleh Subandowo (2017: 206) disebut sebagai transfer bahasa (interfer-

Tabel 2. Hasil Analisis Bunyi

\begin{tabular}{|c|c|c|c|c|c|c|}
\hline No. & Aspek & SSM & SSA01 & SSA02 & SSA03 & Ket. \\
\hline \multirow{3}{*}{1.} & \multirow{3}{*}{$\begin{array}{l}\text { Pengucapan } \\
\text { Bunyi }\end{array}$} & {$[\mathrm{i}]>[\mathrm{i}]$} & [i] > [é] & [i] > [é] & [i] > [é] & $\begin{array}{c}\text { Kosakata } \\
\text { sama. }\end{array}$ \\
\hline & & {$[\mathrm{aw} / \mathrm{au}]>[\mathrm{o}]$} & {$[\mathrm{aw} / \mathrm{au}]>[\mathrm{o}]$} & {$[\mathrm{aw} / \mathrm{au}]>[\mathrm{o}]$} & {$[\mathrm{aw} / \mathrm{au}]>[\mathrm{o}]$} & $\begin{array}{c}\text { Kosakata } \\
\text { berbeda. }\end{array}$ \\
\hline & & $\begin{array}{c}\text { penambahan } \\
\text { bunyi [?] di } \\
\text { akhir kata }\end{array}$ & - & $\begin{array}{c}\text { penambahan } \\
\text { bunyi [?] di } \\
\text { akhir kata }\end{array}$ & - & $\begin{array}{c}\text { Kosakata } \\
\text { sama. }\end{array}$ \\
\hline
\end{tabular}


Tabel 3. Hasil Analisis Penggunaan Bahasa

\begin{tabular}{ccccccc}
\hline No. & \multicolumn{1}{c}{ Aspek } & SSM & SSA01 & SSA02 & SSA03 & Ket. \\
\hline 1. & $\begin{array}{l}\text { Penggunaan } \\
\text { Bahasa }\end{array}$ & $\begin{array}{c}\text { Bahasa } \\
\text { Indonesia }\end{array}$ & $\begin{array}{c}\text { Bahasa } \\
\text { Indonesia }\end{array}$ & $\begin{array}{c}\text { Bahasa } \\
\text { Indonesia }\end{array}$ & $\begin{array}{c}\text { Bahasa } \\
\text { Indonesia }\end{array}$ & $\begin{array}{c}\text { Bahasa } \\
\text { Indonesia }\end{array}$ \\
$\begin{array}{l}\text { Interferensi } \\
\text { Bahasa }\end{array}$ & Bahasa Betawi & Bahasa Jawa & - & Bahasa Jawa & - \\
\hline
\end{tabular}

ensi) yang mengacu pada penutur atau penulis yang menerapkan pengetahuan dari bahasa ibu (B1) ke bahasa kedua (B2). Interferensi adalah efek yang diberikan oleh proses pembelajaran bahasa lain karena latar belakang bahasa pemelajar. Dalam hal ini bahasa pertama GN tentu adalah bahasa Jawa, sedangkan bahasa keduanya adalah bahasa Indonesia.

Kurniati dan Mardikantoro (2010: 275-276) menjelaskan bawa fonem /i/ dalam bahasa Jawa dilafalkan [i], [l], dan $[\varepsilon]$, seperti terlihat pada kata getih 'darah' yang dilafalkan [gətih], [gəthh], dan [gətch]. Selain itu, fonem /e/ dalam bahasa Jawa di Jawa Tengah memiliki dua alofon, yaitu bunyi [e] dan [E], seperti kata kowe [kowe] 'kamu' dan kelek [kelع?] 'ketiak'. Maka, wajar jika GN dalam rekaman SSA01, SSA02 dan SSA03 mengucapkan kata Indonesia dengan bunyi [éndonèsia].

Selain pengucapan [éndonèsia], interferensi bahasa Jawa juga terdapat pada katakata lain seperti pada kata saudara /saudara/ yang seharusnya dilafalkan [sawdara], tetapi pada rekaman SSA01 dan SSA02 diucapkan [sodara]. Aminoedin, dkk. (1984: 125) menjelaskan bahwa bunyi [aw] baik pada posisi tengah maupun posisi akhir dapat beralofon dengan bunyi [o]. Contoh kata lain dari gejala tersebut dapat ditemukan pada kata beliaul bêliau/ yang seharusnya dilafalkan [bêliaw], tetapi pada rekaman SSA01 dan SSA03 diucapkan [bəlio].

Lebih lanjut, interferensi bahasa Jawa pada tataran leksikal juga ditemukan pada rekaman SSA01, yakni kata wong /wOng/ yang berarti dalam bahasa Indonesia adalah 'orang' Kata tersebut disisipkan pada kalimat yang berbunyi "Wong rakyatnya saja berusaha menjadi pahlawan di sini, buktinya, kok." dan "Wong cuma dua, kok." Beda kata, tetapi masih dari rumpun bahasa Jawa, terdapat kata tumbal pada rekaman SSA03. Dalam KBBI (luring), tumbal (nonima) berasal dari bahasa Jawa yang berarti kurban (persembahan dan sebagainya) untuk memperoleh sesuatu (yang lebih baik). Kata tersebut diucapakan dalam kalimat "Saya lebih baik menjadi tumbal untuk melaksanakan tugas menjaga ke-Bhinneka Tunggal Ika-an, daripada saya jadi presiden."

Sementara itu, interferensi bahasa Jawa tidak ditemukan pada rekaman SSM. Namun, pada rekaman tersebut banyak sekali ditemukan interferensi bahasa Betawi. Muhadjir (2000:62-68) menjelaskan ciri khas bahasa Betawi dapat dilihat dari beberapa sudut pandang, yaitu (1) dari ciri pelafalan atau tata ucapnya banyak ditemukan vokal [é] pada kata seperti apé, adé, ayé dan lain-lain, (2) pada tataran kata, adanya suffiks -in, seperti pada kata: ndatengin "mendatangi", ngumpetin "menyembunyikan", nguntitin "mengikuti", dll, (3) pada tataran tata kalimat banyak menggunakan partikel dong, deh, kok, si, kek, dll.

Pada rekaman SSM, terdapat kata dengan pengucapan yang diimbuhi sufiks -in pada kalimat "Pak Jokowi ditambahin lima puluh suara." Kata ditambahin berasal dari bentuk dasar tambah. Secara morfologis, bahasa Indonesia tidak mengenal penambahan konfiks di-in sehingga kata tersebut dapat dinyatakan hanya berimbuhan di- sebagai bentuk pasif menjadi ditambah. Kemudian, bentuk kata berimbuhan ditambah tersebut diucapkan oleh (kemungkinan) orang yang biasa atau bisa dialek Betawi sehingga mendapat imbuhan berupa sufiks -in. Oleh karena itu, kata tersebut menjadi ditambahin.

Selain itu, dialek Betawi dengan penggunaan partikel kek juga ditemukan pada kalimat lain di rekaman SSM. Kalimat tersebut adalah "Jadi kek begitu." atau secara baku berarti 'jadi seperti itu'. Penggunaan partikel kek pada kalimat di atas diucapkan sebanyak dua kali pada rekaman SSM tersebut. Jadi, tidak 
mungkin jika hal tersebut adalah suatu ketidaksengajaan.

\section{Aspek Wacana}

Ditinjau dari aspek wacana, ditemukan penggunaan kohesi gramatikal pada setiap rekaman dalam konteks kalimat yang membicarakan TNI. Adapun alat kohesi tersebut adalah referensi persona. Referensi persona dinyatakan dengan pronomina dan berfungsi untuk menunjukkan individu atau benda. Pada rekaman SSM dan ketiga SSA ditemukan penggunaan referensi persona yang berbeda. Pada rekaman SSM digunakan pronomina jamak orang ketiga, yakni mereka untuk menunjukkan referen TNI, tetapi pada rekaman SSA02 digunakan pronomina jamak orang kedua, yakni kita untuk menunjukkan referen TNI. Sementara itu, pada rekaman SSA01 dan SSA03 tidak digunakan pronomina jamak orang ketiga ataupun kedua, tetapi cukup disebut dengan TNI.

"Undang-undang dua (puluh) dua nomor dua kepada Polri, undang-undang tiga (puluh) empat nomor empat kepada TNI. Mereka adalah pelindung rakyat, tidak ada seorang pun seharusnya (yang) menjadi kacungnya penguasa kalau mereka paham kembali dengan undang-undang tentang mereka lahir." (SSM)

"Ada satu hal yang kritis bahwa kekuatan inti bangsa Indonesia itu adalah bersatunya TNI dan rakyat. Kalo TNI-nya kuat, rakyatnya kuat, negara manapun tidak akan bisa (mengalahkan). (Hal itu) Sudah terbukti, di kota ini sudah terbukti pada saat TNI masih bayi, berumur beberapa bulan, tibatiba sekutu akan menyerang dan mendarat di sini karena rakyatnya TNI-nya bersatu..." (SSA01)

"Kemudian kita mengawal, TNI turun, BKU Kepolisian Republik Rakyat Indonesia, kita mengawal agar saudara-saudara kita ..." (SSA02)

"Presiden memerintahkan, sekali lagi beliau menyampaikan, sebagai panglima tertinggi, saya perintahkan kepada TNI, jaga Ke-Bhennaka-Tunggal-
Ikaan dan TNI sebagai garda terdepan ..."(SSA03)

Hal tersebut berarti bahwa GN pada rekaman SSA02 menyebut dirinya bagian dari TNI karena GN menggunakan pronomina jamak orang kedua, yakni kita. Namun, hal tersebut tidak ditemukan pada rekaman SSA01 dan SSA03. Pada kedua rekaman tersebut memang tidak ditemukan pronomina jamak orang kedua, tetapi referensi persona TNI disebut sebagai "TNI" itu sendiri. Hal itu sama halnya dengan ketika seseorang menyebut namanya sendiri untuk mengganti pronomina persona tunggal orang pertama, yakni saya atau aku. Sementara itu, pada rekaman SSM, pronomina yang digunakan untuk menunjukkan TNI bukanlah kita atau "TNI" itu sendiri, tetapi mereka sehingga dapat dikatakan bahwa orang yang berbicara di rekaman SSM tersebut tidak menyebut dirinya bagian dari TNI.

Selain itu, ditemukan juga kohesi leksikal repetisi pada rekaman SSM. Repetisi merupakan satuan lingual bahasa yang diulangulang untuk penekanan. Repetisi pada rekaman SSM tersebut berupa kalimat, yakni jadi, kek begitu dan jadi, semacam itu. Selama 2.45 detik, pengulangan tersebut total sebanyak 4 kali. Namun, berbeda halnya pada ketiga rekaman SSA. Pada ketiga rekaman tersebut, tidak pernah sekali pun dikatakan kalimat yang sama seperti repetisi pada rekaman SSM. Begitu pun pada rekaman SSA01 yang mempunyai durasi hingga 12.42 detik.

\section{Aspek Stilistika}

Sementara itu, ditinjau dari aspek Stilistika, beberapa diksi tertentu yang digunakan dalam rekaman SSM dan SSA memiliki perbedaan yang cukup signifikan. Perbedaan tersebut terletak pada kecenderungan rekaman SSM digunakan diksi informal, tetapi ketiga rekaman SSA digunakan diksi formal. Sebagai contoh, pada rekaman SSM digunakan diksi usah, tetapi pada rekaman SSA01 digunakan diksi perlu dan diulang sebanyak dua kali.

"Jadi kita nggak usah terpancing juga dengan provokasi mereka.” (SSM) 
“... tapi ini saya perlu infromasikan karena saya mantan panglima TNI agar rakyat bersatu jangan terpecahpecah.." (SSA01)

Kata usah dalam KBBI (luring) edisi V merupakan sebuah kata kerja yang mempunyai arti 'perlu'. Sementara itu, kata perlu merupakan sebuah kata keterangan (adverbial) yang berarti 'harus' atau 'usah'. Walaupun dua kata tersebut mempunyai arti yang sama, tetapi kategori kedua kata tersebut berbeda. Hal tersebut membuat peneliti berpendapat bahwa rekaman SSM dan SSA01 mempunyai gaya berbahasa yang berbeda.

Pada rekaman SSM digunakan diksi udah (baku: sudah), tetapi pada rekaman SSA01, SSA02, dan SSA03 sama sekali tidak pernah digunakan diksi $u d a h$. Hal ini menguatkan pendapat peneliti di atas bahwa memang rekaman SSM mempunyai gaya berbahasa yang berdeda dengan rekaman SSA.

"Dengan melihat masifnya tindak kecurangan ini udah memperlihatkan betapa ambisinya mereka ingin berkuasa untuk periode kedua." (SSM)

"Saya tidak perlu panjang-panjang, pasti Bapak Ibu sudah paham." (SSA01)

"Apa yang kemudian sudah disiapkan oleh Panglima?" (SSA02)

"Umur saya sudah 56, Pak Karni." (SSA03)

Pada rekaman SSM digunakan diksi kacung (penguasa) untuk menggambarkan orang yang melayani (penguasa), tetapi pada rekaman SSA01 digunakan diksi pembantu untuk menggambarkan hal serupa. Kata $\mathrm{ka}$ cung menurut KBBI (luring) edisi $\mathrm{V}$ berarti 'pesuruh, pelayan, jongos (biasanya anak lakulaki)', sedangkan pembantu berarti 'orang (alat dan sebagainya) membantu; penolong'. Kata pembantu mempunyai dua arti, arti kedua yakni 'orang upahan, pekerjaanya (membantu) mengurus pekerjaan rumah tangga (memasak, mencuci, menyapu, dan sebagainya)'. Dari penjelasan tersebut dapat ditarik kesimpulan bahwa kata kacung mempunyai makna kono- tasi atau nuansa rasa yang lebih buruk dibandingkan dengan kata pembantu. Hal tersebut semakin menambah bukti bahwa rekaman SSM dan SSA01 adalah dua rekaman yang mempunyai dua gaya berbahasa yang berbeda.

"Mereka adalah pelindung rakyat, tidak ada seorang pun seharusnya menjadi kacungnya penguasa kalau mereka paham kembali dengan undang-undang tentang mereka lahir." (SSM)

"Kalau kita tidak waspada maka zaman penjajahan kita pembantu, kemerdekaan jadi pembantu, sekarang pun keturunannya pembantu dan nanti pun akan menjadi pembantu." (SSA01)

\section{SIMPULAN}

Berdasarkan uraian hasil penelitian dan pembahasan yang telah disajikan di atas, temuan kajian tentang Linguistik Forensik dalam penelitian yang berjudul "Studi Kasus Linguistik Forensik: Hoaks Rekaman Suara yang Diduga Gatot Nurmantyo" ini secara singkat dapat dirangkum sebagai berikut.

Pertama, ditemukan perbedaan yang signifikan antara bahasa pada rekaman SSM dan bahasa padaketiga rekaman SSA ditinjau dari aspek Sosiolinguistik, Wacana dan Stilistika. Dari aspek Sosiolinguistik, secara keseluruhan bahasa yang digunakan dalam setiap rekaman adalah bahasa Indonesia, tetapi perbedaanya adalah bahasa dalam rekaman tersebut terinterferensi oleh bahasa daerah yang berbeda, yakni SSM oleh bahasa Betawi, sedangkan SSA oleh bahasa Jawa. Dari aspek Wacana, referensi persona yang digunakan untuk menunjukkan referen TNI berbeda, yakni pada rekaman SSM digunakan pronomina jamak orang ketiga (mereka), sedangkan pada rekaman SSA digunakan pronomina jamak orang kedua (kita)dan "TNI" itu sendiri. Dari aspek Stilistika, perbedaan tersebut terletak pada kecenderungan rekaman SSM digunakan diksi informal, tetapi ketiga rekaman SSA digunakan diksi formal.

Kedua, ditemukan kecenderungan kemiripan di beberapa bagian pada aspek Fonologi meliputi durasi pengucapan kata, intensitas energi pengucapan kata, dan bunyi kata. Pada 
rekaman SSM, kata Indonesia diucapkan selama 0.562976 detik (1.776/s) dan pada rekaman SSA02 diucapkan selama 0.539233 (1.854/s). Kemudian, dengan pengucapan kata yang sama, rekaman SSM mempunyai rata-rata intensitas energi $78.97009834060798 \mathrm{~dB}$ dan rekaman SSA03 adalah 79.02895534199254 dB. Kemiripan bunyi kata terletak pada kata kalau pada rekaman SSM dan SSA01, yang diucapkan menjadi [kalo] dan kata juga yang diucapkan menjadi [jugaA] pada rekaman SSM dan SSA02.

Oleh kerena itu, merujuk pada Skala Kemungkinan Klasik (Classical Likelihood Scales) berarti kemungkinan besar rekaman SSM dan SSA bukan dari penutur yang sama. Pada akhirnya, penelitian ini diharapkan mampu menjadi pemantik untuk mengembangkan kajian Linguistik Forensik di Indonesia guna dapat membantu para penegak hukum dalam menyelesaikan kasus-kasus yang ditangani dan juga membantu korban yang mengalaminya.

\section{DAFTAR PUSTAKA}

Aminoedin, Ny. A., dkk. (1984). Fonologi Bahasa Indonesia: Sebuah Studi Deskriptif. Jakarta: Pusat Pembinaan dan Pengembangan Bahasa Departemen Pendidikan dan Kebudayaan.

Chaer, A. dan Leonie A. (2010). Sosiolinguistik Perkenalan Awal. Jakarta: Rineka Cipta.

Coulthard dan Johnson. (2007). An Introduction to Forensic Linguistics: Language in Evidence. From https://pasca. uns.ac.id/s3linguistik/wp-content/ uploads/sites/44/2016/10/Malcolm Coulthard_Alison_Johnson.pdf

French, P. (2017). A Developmental History of Forensic Speaker Comparison in the UK. From $h \mathrm{ttp}: / /$ eprints.whiterose. ac.uk/117763/7/Developmental_History of Forensic Speaker Comparison in the_UK.pdf

Halliday, M.A.K. \& Ruqaiya Hasan. (1976). Cohesion in English. London: Longman.

Kurniati dan Mardikantoro. 2010. "Pola Variasi Bahasa Jawa (Kajian Sosiodialek- tologi pada Masyarakat Tutur di Jawa Tengah)" dalam Jurnal Humaniora Vol. 22, Oktober, Hlm. 273-284. https:// jurnal.ugm.ac.id/jurnal-humaniora/article/view/1001/832

Lindh, J. (2017). Forensic Comparison of Voices, Speech and Speakers: Tools and Methods in Forensic Phonetics. From https://gupea. ub.gu.se/bitstream/2077/52188/4/ gupea_2077_52188_4.pdf

Muhadjir. (2000). Bahasa Betawi: Sejarah dan Perkembangannya. Jakarta: Yayasan Obor Indonesia.

Mukattash, BK. (2016). "The Role of Forensic Phonetics in Legal Investigation: A Case Study of Two Speaker-Identified/ Unidentified Recorded Samples" dalam Journal of Literature, Languages and Linguistics, IISTE, Vol. 29, hlm. 31-37. https://iiste.org/Journals/index. php/JLLL/article/view/34706

Olsson, J. (2004). ForensicLinguistics. From https://linguistlist.org/issues/15/152774.html

Pitoyo, A. (2017). "Interferensi Bahasa Jawa ke dalam Bahasa Indonesia Mahasiswa Program Studi Pendidikan Bahasa dan Sastra Indonesia dalam Perkuliahan Keprotokolan" dalam Jurnal Pena Indonesia (JPI), Vol. 3 No. 2, hlm. 185200. https://journal.unesa.ac.id/index. php/jpi/article/view/2131

Setiawan dan Hidayat. (2015). "Referensi Bahasa Jawa ke dalam Bahasa Indonesia pada Keterampilan Berbicara Siswa Negeri 1 Pleret, Bantul" dalam Jurnal Lingtera, Vol. 2, hlm. 156-168. https:// eprints.uny.ac.id/12060/

Subandowo, D. (2017). "The Language Interference in English Speaking Ability for Efl Learners" dalam ISELT-6. Padang: Universitas Negeri Padang. https://www.researchgate.net/ publication/320199876 The Language_Interference_in_English_ Speaking_Skill_for_EFL_Learners

Subyantoro. (2017). "Langkah Prof Subyantoro Kembangkan Linguistik Foren- 
sik di Indonesia" dalam artikel yang dimuat oleh Universitas Negeri Semarang. https://unnes.ac.id/berita/langkah-prof-subyantoro-kembangkan-linguistik-forensik-di-indonesia/

Susanto. (2017). "Potensi dan Tantangan Linguistik Forensik di Indonesia" dalam ILSIA III. Jakarta: Ikatan Ilmuwan Indonesia Internasional. https://i4indonesia.org/wp-content/uploads/2018/03/ ILSIA_III-2017_ISBN_978-60274602-3-2.pdf
Tarigan, Henry Guntur. (2009). Pengajaran Wacana. Bandung: Angkasa.

Thomason, S. (2001). Languange Contact. From http://www-personal.umich. edu/ thomason/temp/lgcont1.pdf

Widyamartaya, A. (1990). Seni Menuangkan Gagasan. Yogyakarta: Penerbit Kanisius. 